\title{
Evaluation on corporate social responsibility issues in the view of hotel business in CALABARZON region, Philippines
}

\author{
Borbon, Noelah Mae D. $\unrhd$ \\ Lyceum of the Philippines University-Batangas, Philippines (nmdborbon@lpubatangas.edu.ph)
}

Received: 25 May 2020

Revised: 15 June 2020 DOI: $10.5861 /$ ijrse.2020.5818

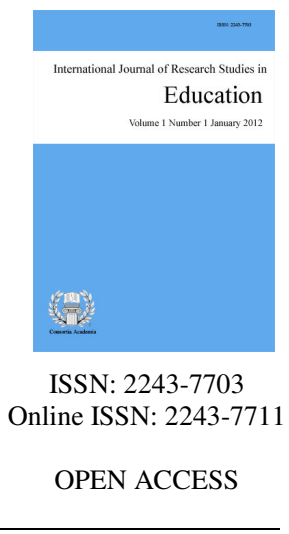

\section{Abstract}

The CALABARZON region is naturally gifted with natural, cultural and historical advantage in hospitality since of the friendliness of its people and its natural wonders that are yet to be fully harnessed. Being one of the most hospitable and naturally welcoming when it comes to accommodation, the region ensures every tourist to be accommodated. It is evident in any hotel establishment where most of the hotel products are costly the guest is experience satisfaction whenever they were accommodated by the hotel employees who are influential and has a good customer service. This is being developed through participating hotel's Corporate Social Responsibility. The study aims to evaluate the issues with regards to corporate social responsibility of various accredited Hotel establishment in CALABARZON region. The researcher in this study used the descriptive research method. Upon the data gathering, a total of one hundred thirty (130) respondents from the forty-five (45) hotel establishment were collected. The research found out that climate change and population growth is the most common problems encountered as economic issue in the corporate social responsibility implementation of the hotels. It implies that classification of the accommodation establishment is not a factor that determines the level of problems encountered in political, economic and social aspects.

Keywords: CSR; economic issues; hotel industry; political issues; social issues 


\section{Evaluation on corporate social responsibility issues in the view of hotel business in CALABARZON region, Philippines}

\section{Introduction}

Over the last decades, tourism, specifically under accommodation management, is being aggressively damaged by variety of challenges. To name a few, there are war and terrorism attacks around the globe, recession as a result of economic crises, political dynasty and social problems. Each of these, and their consequences on the economic growth of the hotel chains. Furthermore, Gallego and Li (2016) confirm that there is a necessity to comprehend and have a deeper study with regards to these problems encountered by the hotel establishment so that these problems will be resolved.

There is a challenge for hotels and, in fact, all companies wanting to conduct corporate social responsibility measures, lies in the measurement of corporate social responsibility performance. This includes the measurement of secretions, garbage, supply usage, work-related and client's well-being and security, anti-competitive performance and non-discrimination, amongst others (Yadava \& Sinha, 2016). Once the corporate social responsibility activity has started, the objective is transformed into the acquisition of new portions of the market: the hotel managers shall be efficient in deciding to maximize all the available resources may it be internal resources from the manpower, materials and money, or external resources from getting sponsorship and partnership with other corporation. The ratio economic of the aggregations and exploits itching of economies of scale in the production of value added. The expected effect is to rebalance the debit positions of the individual hotel businesses (Milone, Toccoli, \& Zappia, 2015).

In this generation, still, violence partakes an undesirable effect on tourism however its effect is being lessened as compared to governance (Yap \& Saha, 2013). Though, there are still people who tend to travel, and check in to hotel and resorts amidst of the terrorism. Experience of veteran hotel managers reveals that the sustainable program implementation can be challenging on the part of any hospitality businesses most specifically the small enterprises like resorts and inns, but there are still coping up to these challenges by applying the cluster approach that can deliver a stronger track to sustainability whereas it also contributing support and proper funding on resources and cost (McLennan, Becken, \& Watt, 2013).

The study aims to answer the following objectives: present the profile of the hotel industry in CALABARZON in terms of: classification of the accommodation; location accessibility; and number of years of operations; identify the issue by the accommodation establishment in their compliance to corporate social responsibility in terms of: political issues; economic issues; and social Issues. Furthermore, the study will test the significant difference on the CSR issue with regards to corporate social responsibility when grouped according to the hotel profile. Based on the results, this study will recommend action plan for continuous improvement for hotel industry.

\section{Methodology}

\subsection{Research Design}

The researcher in this study used the descriptive research method. Ritchie (2013) believe with the use of descriptive method, the researcher needs to be observant into a larger crowd and there is a necessity to include variables to the conclusion. The researcher by using descriptive research can effectively design a pre-structured questionnaire with both open ended and closed ended questions. In this study, researcher used a triangulation which concentrate on the issues in CSR of the hotel industry in CALABARZON. Moreover, the researcher 
utilized a self-made survey questionnaire, interview and observation and focus group discussion.

\subsection{Participants of the study}

The respondents of the study are the employees of the Department of Tourism (DOT) accredited hotel industry. The researcher emailed the DOT regional director to have the updated list of accredited hotel, resorts and tourist's inn in CALABARZON region. Appendix C contains the update list of the respondent. Out of seventy-six (76) hotel, resort, tourist inn and hotel-resort, 45 or $59.2 \%$ participated in the study. Selected Employees who are working in the establishment answered the questionnaire and the manager and supervisor was interviewed while those employees who answered the questionnaires participated the focus group discussion. Upon the data gathering, a total of one hundred thirty (130) respondents from the forty-five (45) hotel establishment were collected. Referring to Table 1 presents the profile of the hotel establishment. Half of the respondents are classified as hotel with the frequency of 65. This data also implies that this study has recorded greater hotels that are in Batangas which may exist for almost 6 years. CALABARZON region is well-known to be a region full of cultural and natural attraction, where a lot of hotel and resort is being enjoyed by tourist locally and internationally.

\section{Table 1}

Respondent's demographic profile

\begin{tabular}{lcc}
\hline Classification of the hotel establishment & $n$ & $\%$ \\
\hline Hotel & 65 & 50.0 \\
Resort & 48 & 36.9 \\
Tourist Inn & 17 & 13.1 \\
\hline$\quad$ Location accessibility & 35 & 26.9 \\
Cavite & 9 & 6.9 \\
Laguna & 65 & 50.0 \\
Batangas & 10 & 7.7 \\
Rizal & 11 & 8.5 \\
Quezon & & \\
No. of years of operations & 23 & 17.7 \\
5 years & 48 & 36.9 \\
6- 10 years & 24 & 18.5 \\
11 - 15 years & 28 & 21.5 \\
16- 20 years & 7 & 5.4 \\
21 years and above & & \\
\hline
\end{tabular}

\subsection{Instruments of the study}

The instrument used was self-made questionnaires which are clustered into two parts. First part was the profiling of the respondents to determine classification of the accommodation; location accessibility; number of employees; number of years of operations: and estimated annual hotel guest. The second part is assessing the issues in CSR of the accredited hotel establishment in CALABARZON. The self-made questionnaire was derived from different researches and CSR output which undergone a reliability test to check the validity and reliability. The reliability test was answered by those non accredited and expert faculty from the College of International Tourism Hospitality Management. The result of reliability statistics showed that it obtained a Cronbach's alpha value of .898 which signifies good in the rule of thumb. Thus, this set of questionnaires is considered valid for use.

\subsection{Data gathering procedures}

After the approval of the proposed topic by Dissertation Writing Professor and the Program Chair for PhD IHM, the researcher administered the questionnaire to the target respondents. With the use of the official website for each hotel establishment and its Facebook account, the researcher was able send a request letter indicating 
the intent to conduct the survey. There are some hotels who responded positively to answer the questionnaires through an online google form, and some of the hotels refused to answer in compliance of their data privacy policy, some were just so busy of the operation since it was summer-peak season however, there hotel that has no response at all and not interested to be part of the study. The researcher visited the hotel establishments to conduct the actual administration of survey and within the given span of time, the researcher set an interview for those managers who are willing to be interviewed and focus group discussion with the hotel employees.

\subsection{Data analysis}

Personal encoding was successfully done after gathering all the data and SPSS was used to interpret and analyzed the data gathered. This study used frequency distribution, percentage and weighted mean as statistical tools for the first part of the questionnaire, presenting the profile of the respondents. The use of the weighted mean was applicable to determining the issue in CSR of the hotel establishment while ANOVA was used to test the significant difference

\section{Results and discussions}

\section{Table 2}

Corporate social responsibility in terms of political issues

\begin{tabular}{|c|c|c|c|}
\hline Political issues & WM & VI & $\mathrm{R}$ \\
\hline There are no NGO/LGU supporting the hotel's CSR initiatives & 2.72 & $\mathrm{O}$ & 1.5 \\
\hline $\begin{array}{l}\text { There are lack of appropriate revenue transparency and corporate and government } \\
\text { accountability }\end{array}$ & 2.72 & $\mathrm{O}$ & 1.5 \\
\hline $\begin{array}{l}\text { There are different negative views on the effectiveness of regulatory and voluntary } \\
\text { mechanisms of the hotel and LGU. }\end{array}$ & 2.57 & $\mathrm{O}$ & 3 \\
\hline $\begin{array}{l}\text { Corporate giving has changed into a more political activity as companies have increasingly } \\
\text { taken on responsibilities traditionally left to governments }\end{array}$ & 2.49 & S & 4 \\
\hline The politicians have controlled over CSR of the Hotel & 2.29 & $\mathrm{~S}$ & 5 \\
\hline Composite Mean & 2.56 & $\mathrm{O}$ & \\
\hline
\end{tabular}

Note. Scale: 3.50-4.00: Always (A); 2.50-3.49: Often (O); 1.50-2.49: Sometimes (S); 1.00-1.49: Never (N).

Table 2 presents the political issues in CSR which has the computed composite mean score of 2.56 implies that the hotel has fewer difficulties in CSR in terms of political issue. First in the rank is having support coming from the national and local government units (2.72). Local government units in CALABARZON are supporting the CSR initiatives of the hotel industry. This was been confirm by one of the hotels whose recent commenced CSR activity was concert for a cause. This concert was assisted and fully supported by government through giving assistance to its safety and personally participated by attending the said concert. On the bigger scale, national government units supporting the CSR are evidently seen in one of the resorts who were largely damaged by the recent Haiyan typhoon. The national government helps out by giving donation to rehabilitated most especially the damaged infrastructure such as roads and bridges. Government officials coming from different countries ordain regulations that would create motivation for hotel establishments by creating subsidies (Punitha \& Rasdi, 2013). With this financial support hotel establishment would be more encouraged to create and participate in more CSR initiatives in improving quality of life.

Likewise, According to Tingchi Liu, Anthony Wong, Shi, Chu, and Brock (2014) government initiative and support are the primary driver in the CSR activity relating to environment. There should be a desire to initiate coming from the national leaders down to private businesses. This is important factor to solve the emerging political issue having no support of government units to CSR.

Lack of corporate and government accountability for revenue transparency (2.72). Traditionally, the financial transparency's interest was being studied and have been topic from recent researches since it is one of the important issues politically (Vallespín, 2016). These has been the focus of the local and national government units prioritizing to be transparent in all aspect. However, According to Carlitz (2013) there is really no specific 
ingredient to obtain success in achieving government accountability and transparency. This is a political issue for a hotel establishment since one of there are requirements as a business entity is to comply to all the rules and regulations embodied by the government such as compliance the Republic Act number 9003 or commonly known as the Ecological Solid Waste Management Act of 2000 so the hotel has the responsibility to ensure there is a waste management plan and segregation as well as recycling process. Correspondingly, Hotels as a service provider, ensuring the health and welfare of every guest in compliance to Presidential Decree No. 856 of 1975. Code on Sanitation on the Philippines.

Next in the rank is that there are different negative views on the effectiveness of regulatory and voluntary mechanisms of the hotel and LGU (2.57) There is a challenge for hotels and, in fact, all companies wanting to conduct Corporate Social Responsibility measures, lies in the measurement of CSR performance. This includes the measurement of secretions, garbage, supply usage, work-related and client's well-being and security, anti-competitive performance and non-discrimination, amongst others (Yadava \& Sinha, 2016). Not only on CSR performance but also with regards to the regulatory effectiveness and voluntary mechanism has been challenging for hotels as there are different negative views on these matters.

Corporate giving has changed into a more political activity as companies have increasingly taken on responsibilities traditionally left to governments (2.49) ranked fourth. The findings of one research indicate that there is an expectation to the national government officials to cooperate with small businesses, including the accommodation establishment in providing financial aid to organizations like charity or social group of people helping the community. This financial aid may be materially equivalent like goods and products that is related to the host community. This act may refer to "goodness of the heart". This is a stakeholder approach to CSR, that the hotel top management shall be held responsible to a great potential in understanding how their hotel could deal with the variety of suppliers and stakeholder that can have an effect better managed for effective CSR implementation, particularly as diverse stakeholder interests were identified as core to the implementation problem.

The politicians have controlled over CSR of the Hotel (2.29) gets the lowest obtained weighted mean as it ranks last. The hotel and resorts used to find partnership with non-hotel stakeholders to fulfill their plans in CSR. These tactics has been used overtime to maximize and solve issues on social and environmental (Smith \& Ong, 2015). These non-hotel stakeholders are mostly businesses, educators and private individuals. Politicians are note included thus have their own individual social responsibility rather than taking part of other's CSR. This concept also shows the little of attention the politician gives in order to arrange politics that dealing with environmental issues. Thus, private sectors be the pioneer or main actor in campaigning the global issues about environment. Being the last in the rank may signifies that the problem encountered in terms of political issue is not that grave and thus gives positive view that the hotel and resort is doing just well in their CSR.

\section{Table 3}

Corporate social responsibility in terms of economic issues

\begin{tabular}{|c|c|c|c|}
\hline Economic issues & WM & VI & $\mathrm{R}$ \\
\hline There is a lack of sustainable CSR Development Plan & 2.54 & $\mathrm{O}$ & 5 \\
\hline Profit maximization is one of the key motives for CSR & 2.68 & $\mathrm{O}$ & 4 \\
\hline Hotel use CSR to differentiate and advertise their product or to build brand loyalty. & 2.78 & $\mathrm{O}$ & 2 \\
\hline $\begin{array}{l}\text { Climate change and population growth has as a negative effect to CSR implementation of the } \\
\text { hotel }\end{array}$ & 2.86 & $\mathrm{O}$ & 1 \\
\hline CSR involvement has no effect on the profitability of the hotel & 2.69 & $\mathrm{O}$ & 3 \\
\hline Composite Mean & 2.71 & $\mathrm{O}$ & \\
\hline
\end{tabular}

Note. Scale: 3.50-4.00: Always (A); 2.50-3.49: Often (O); 1.50-2.49: Sometimes (S); 1.00-1.49: Never (N).

Table 3 Economic issues in CSR which as the computed composite mean score of 2.71 implies that the hotel has less complications in CSR in terms of economic issue. First in the ranking is that the climate change and population growth have a negative effect in implementing CSR activities (2.86). One of the most commonly practiced CSR by hotels, resorts and tourist inn are environmentally friendly activity addressing the emerging 
issue on climate change as well as social community development to address population growth. These problems with climate change and population growth is directly affecting the economic development of the industry since climate change and population growth is one of global economic-environmental issue. Thus, making it the first in the rank only means that in hotel industry, this issue on climate change and population growth is not literality affecting negatively in implementing corporate social responsibility activities of hotels and resorts. Given the emerging complex economic issue, there is on way to achieve profitability in the hotel industry for long term and that is through CSR (Cech, \& Dohnalova, 2015).

Second in the rank is that the hotel uses CSR to differentiate and advertise their product or to build brand loyalty (2.78). For a hotel, resort and tourist inn who go directly to the nearby community and conduct their CSR activity has the ultimate goal of improving the quality of life and be of help to the community as giving back of the hotels. Thus, this act may have secondary goal of making their brand name uplifted and known by the community. This may be for advertisement or building good image and create customer loyalty. It is undeniably factual that the hotel, resorts and tourist inn are engaging into CSR activity to build up their image to the public which will eventually result to advertise their product and build customer loyalty. Moreover, According to Lin, (2017) the corporate social responsibility of the hotel, resort, and may it be tourist's inn produces positive effect on the brand loyalty as well as increasing the performance of their employee as well as it is because of the corporate social responsibility of the hotel's initiative that motivates to have positive outcome on the customer satisfaction resulting to guest delight (Goyal \& Chanda, 2017).

Furthermore, CSR involvement has no effect on the profitability of the hotel (2.69) ranked third. This may result to an improved the hotel performance and profitability. Cost savings in hotel operations are often evidenced through CSR implementation, particularly environmentally- responsible practices which reduce energy expenses. This is a major motivating factor for hotel properties to implement green practices. Since based on the research findings of Liu et al. (2017) suggested to hospitality industry to observe their employee's engagement to CSR to create awareness and self fulfilment to organizational sustainable projects.

Moreover, profit maximization is one of the key motives for CSR (2.68). One of the reasons why people engage into business is making profit. In any business-service industry especially for hotels, resorts and tourist inn reduction of the cost to increase the profit is one of their strategies. The management made use of CSR to lessen their tax since the expenditure for CSR activity are normally deducted to their tax as sited by one of the resort managers in Batangas. As Gao and Mattila (2014) perceived that the friendliness and capability of the hotel employees may intervene with the service results and guest's delight. The hotel employees are considered to be more effective when they were motivated thus in return customer will be satisfied. Furthermore, Cheon, (2016) revealed that the factor of public or social dimension and legal order has a significant influence on quality value, price value, and customer satisfaction. Also, quality value and price value have significant influences on customer satisfaction. This is being developed through participating hotel's CSR.

However, lacking the sustainable CSR Development Plan (2.54) ranked lowest. In this generation, still, violence partakes an undesirable effect on tourism however its effect is being lessened as compared to governance (Yap \& Saha, 2013). Though, there are still people who tend to travel, and check in to hotel and resorts amidst of the terrorism. Experience of veteran hotel managers reveals that the sustainable program implementation can be challenging on the part of any hospitality businesses most specifically the small enterprises like resorts and inns, but there are still coping up to these challenges by applying the cluster approach that can deliver a stronger track to sustainability whereas it also contributing support and proper funding on resources and cost (McLennan, et.al., 2013). The Hotel should consider creating organizational sustainable development plan for CSR. This would be helpful since CSR can be utilized as an efficient and appropriate instrument for sustainable tourism development (Goyal \& Chanda, 2017). 


\section{Table 4}

Corporate social responsibility in terms of social issues

\begin{tabular}{|c|c|c|c|}
\hline Social issues & WM & VI & $\mathrm{R}$ \\
\hline $\begin{array}{l}\text { The business benefits of corporate responsibility programs are not always immediately } \\
\text { tangible. }\end{array}$ & 2.78 & $\mathrm{O}$ & 1 \\
\hline There is a lack of consensus amongst local agencies regarding CSR projects. & 2.67 & $\mathrm{O}$ & 2 \\
\hline $\begin{array}{l}\text { There is a lack of interest of the local community in participating and contributing to CSR } \\
\text { activities of companies. }\end{array}$ & 2.66 & $\mathrm{O}$ & 3 \\
\hline $\begin{array}{l}\text { There is non-availability of well-organized nongovernmental organizations in remote and rural } \\
\text { areas that can assess and identify real needs of the community. }\end{array}$ & 2.55 & $\mathrm{O}$ & 5 \\
\hline $\begin{array}{l}\text { Lack of reliable indicators of progress in the field of CSR, along with the dissemination of } \\
\text { CSR strategies }\end{array}$ & 2.56 & $\mathrm{O}$ & 4 \\
\hline Composite Mean & 2.64 & $\mathrm{O}$ & \\
\hline
\end{tabular}

Note. Scale: 3.50-4.00: Always (A); 2.50-3.49: Often (O); 1.50-2.49: Sometimes (S); 1.00-1.49: Never (N).

Table 4 Social issues in CSR which as the computed composite mean score of 2.64 implies that the hotel has fewer worries in CSR in terms of social issue. First in the rank is that the business benefits of corporate responsibility programs are not always immediately tangible (2.78). This rank first, basically because the CSR return over may be evidently seen immediately. Whereas, there is a lack of consensus amongst local agencies regarding CSR projects ranked second with 2.67 as weighted mean. There is a lack of consensus among local agencies concern project relating to CSR. This lack of consensus often results in duplication of activities by corporate houses in areas of their intervention. This results in a competitive spirit between local implementing agencies rather than building collaborative approaches on issues. This factor limits company's abilities to undertake impact assessment of their initiatives from time to time (Prabhakar \& Mishra, 2013).

Following in the rank, there is a lack of interest of the local community in participating and contributing to CSR activities of companies. (2.66). Lack of interest of local community may be affected by several factors that is why the hotels must concentrate on creating attractive skills development center for all ages and both women and men. Recruiting local residence living in the community may also be invited to educational awareness and environmental campaign, and less prioritize the donation giving to local to prevent spoon feeding (Jogdand \& Sawant, 2013). Moreover, Hospitality establishments must incorporate corporate social responsibility edges with regards to maintainable approach to develop their worker. Business standards is being refined amongst personnel by participating the CSR initiatives of hotel, resorts and tourist inn and engaging in any activity related to the corporate social responsibility where their social skills are being observed (Luu, 2017).

Moreover, Lack of reliable indicators of progress in the field of CSR, along with the dissemination of CSR strategies (2.56). There is a challenge for hotels and, in fact, all companies wanting to conduct CSR measures, lies in the measurement of CSR performance. This includes the measurement of secretions, garbage, supply usage, work-related and client's well-being and security, anti-competitive performance and non-discrimination, amongst others (Yadava \& Sinha, 2016). According to Priya (2014) one of the challenges that the hospitality industry is facing is the need to look into more reliable indicator to measure the progress of CSR. As well as there are few indicators relating to the measurement of standards which make it difficult to standardize the CSR progress (Ingram, de Grip, de Wildt, Ton, Douma, Boone, \& van Hoeven, 2013). Even the word CSR, there is really no define definition to it as to measuring through reliable indicators is not given that is the reason why having a sustainable plan is essential.

There is non-availability of well-organized nongovernmental organizations in remote and rural areas that can assess and identify real needs of the community. (2.55) obtained the lowest rank. The participation to any CSR activity can add destruction the communal structure of local and international health care since based on the findings, the volunteers are untrained (Smith, 2015). For the volunteering of any hotel staff shall be proper training to be done so that this act may not put into waste as far as damaging the community. This ranked last in the problems encountered since the hotel and resort responded that there is partnership among non-hotel 
Borbon, N. M. D.

stakeholders helping them in their CSR initiatives and promoting community development.

Table 5

Issues in CSR when grouped according to profile variable

\begin{tabular}{lccccccccc}
\hline & \multicolumn{3}{c}{ Classification of Hotel } & \multicolumn{3}{c}{ Location } & \multicolumn{3}{c}{ No. of Years in Operation } \\
\cline { 2 - 10 } & $F$ & Sig. & I & $F$ & Sig. & I & $F$ & Sig. & I \\
\hline Political & 2.878 & .060 & NS & $4.328^{* *}$ & .003 & S & 4.959 & .001 & S \\
Economic & 1.316 & .272 & NS & $4.460^{* *}$ & .002 & S & 5.730 & .000 & S \\
Social & 1.565 & .213 & NS & $5.046^{* *}$ & .001 & S & 7.580 & .000 & S \\
\hline
\end{tabular}

Note. ${ }^{*} p<.05$.

In Table 5, no significant difference exists on the problems encountered by the respondents on CSR when grouped according to classification as denoted by the computed p-values which are greater than 0.05 alpha level. It implies that classification of the accommodation establishment is not a factor that determines the level of problems encountered in political, economic and social aspects. Whatever the classification of the establishment, may it be a hotel, resort and tourist inn, every accommodation establishment encountered problems with regards to political, economic and social. It is but natural for a business establishment to experience problem, but the classification of the establishment is not a factor.

There are an increasing number of companies who are actively observing CSR. The hotel, resorts and tourist inn are continuing CSR efforts to local communities that are located around their vicinity (Amran, Zain, Sulaiman, Sarker, \& Ooi, 2013). Though, the classification of the accommodation doesn't affect to the problems and issues that they are facing. Moreover, Vveinhardt and Andriukaitiene (2017) suggested that the CSR theories is not applicable to perform in a manner that is consistent, regardless that the corporate social responsibility is integrated in a much formal setting where it is already a part of the company's culture once the hotel management will put everything into daily practice there and then Philanthropical act will become natural for them without formal reminder. This is the goal of every hotel chain, to be a catalyst for change, change for better lives among their beneficiaries.

Furthermore, Data showed in Table 5 that significant difference exists on the problems encountered with CSR in terms of political (.003), Economic (.002) and Social (.001) when grouped in terms of location according to province as denoted by the computed p-values which are less than .01 alpha level. It implies that the group of respondents from Rizal has significantly higher level of problems encountered with CSR compared to Laguna and Batangas.

Geographically every accommodation establishment has its own strengths and weaknesses. Even though it is located in one single region which is CALABARZON, still there are a lot of complexity that should be considered. According to Philippine Statistics Authority (2018) CALABARZON is located in southern Luzon which is south and west of Metro Manila and is considered to be as the second most densely populated region. According to Dhaliwal, Li, Tsang and Yang (2014), CSR is one of the strategies used by companies for cost reduction. The geographical location is one of the factors to define the expenditures of the hotel thus affecting the CSR in a way that the hotel should adopt to the province's regulating body referring to the political and economic aspect and cultural differences in terms of social aspect.

Also, Data showed in Table 5 that significant difference exists on the problems encountered with CSR in terms of political (.001), Economic (.000) and Social (.000) when grouped according to number of years in operation as denoted by the computed $p$-values which are less than .01 alpha level. Results of Post Hoc Test revealed that those respondents from accommodations with 11 to 15 years in operation have significantly higher problems encountered in political aspect compared accommodations with 6 to 10 years. Meanwhile, the group of respondents from accommodations having 16 to 20 years has significantly lower problems encountered in terms of economic aspect. Likewise, respondents from accommodation having 11 to 15 years in operation have significantly higher problems encountered in terms of social aspect compared to those respondents from 6 to 10

48 Consortia Academia Publishing (A partner of Network of Professional Researchers and Educators) 
years and 16 to 20 years in operation.

In today's generation, there is a massive growing number of businesses that are implementing different CSR initiatives - the voluntary incorporation of social and environmental issues into a company's business model and operations (Ioannou \& Serafeim, 2015). This only proves no matter how long the business is operating, there is a tendency that they would experience political, economic and social issue. The only difference is how serious the issues are. It is the responsibility of the management to cope up these issues.

\section{Conclusion and recommendation}

Hotel establishment around CALABARZON are mostly located around coastal area that exist for more or less than 20 years providing accommodation and luxury to tourist away from home. Climate change and population growth is the most common problems encountered as economic issue in the corporate social responsibility implementation of the hotels. It implies that classification of the accommodation establishment is not a factor that determines the level of problems encountered in political, economic and social aspects. Respondents from Rizal has significantly higher level of problems encountered with CSR compared to Laguna and Batangas. Respondents from accommodation having 11 to 15 years in operation have significantly higher problems encountered in terms of social aspect compared to those respondents from 6 to 10 years and 16 to 20 years in operation.

Since Climate change and population growth is the most common problems encountered, hotel, resorts and tourist inn may focus to these issues by coming up with an awareness program to their benefactors that would result to save the environment which will be posted in an infographic to ensure transparency to the society. This study is limited to CALABARZON region with employees of accommodation establishment as respondents. Further studies are recommended to explore the level of participation of the employees in the CSR programs and projects of their respective organization and how those activities influence this social responsiveness for community development.

\section{References}

Amran, A., Zain, M. M., Sulaiman, M., Sarker, T., \& Ooi, S. K. (2013). Empowering society for better corporate social responsibility (CSR): The case of Malaysia. Kajian Malaysia, 31(1), 57.

Carlitz, R. (2013). Improving transparency and accountability in the budget process: an assessment of recent initiatives. Development Policy Review, 31(s1). https://doi.org/10.1111/dpr.12019

Cech, P., \& Dohnalova, M. (2015). How corporate social responsibility can contribute to growth strategy. In International conference knowledge-based organization (Vol. 21(1), pp. 160-164). https://doi.org/10.1515/kbo-2015-0026

Conley, J. M., Lázaro-Muñoz, G., Prince, A. E., Davis, A. M., \& Cadigan, R. J. (2015). Scientific social responsibility: lessons from the corporate social responsibility movement. The American Journal of Bioethics, 15(12), 64-66. https://doi.org/10.1080/15265161.2015.1103812

Dhaliwal, D., Li, O. Z., Tsang, A., \& Yang, Y. G. (2014). Corporate social responsibility disclosure and the cost of equity capital: The roles of stakeholder orientation and financial transparency. Journal of Accounting and Public Policy, 33(4), 328-355. https://doi.org/10.1016/j.jaccpubpol.2014.04.006

Farmaki, A., \& Farmakis, P. (2018). A stakeholder approach to CSR in hotels. Annals of Tourism Research, 68, 58-60. https://doi.org/10.1016/j.annals.2017.11.009

Gallego, M. S., \& Li, S. (2016) Special issue on tourism and instability. https://doi.org/10.1080/19407963.2017.1269766

Gao, Y. L., \& Mattila, A. S. (2014). Improving consumer satisfaction in green hotels: The roles of perceived warmth, perceived competence, and CSR motive. International Journal of Hospitality Management, 42. ttps://doi.org/10.1016/j.ijhm.2014.06.003

Goyal, P., \& Chanda, U. (2017). Impact of CSR on customer satisfaction and trust: A study of Indian Hotel 
Industry. In 5th international conference on contemporary marketing issues (p. 377). Thessaloniki, Greece.

Huimin, G., Hui, J., \& Yaxing, Z. (2017). Study on the impact of corporate social responsibility on hotel employees' turnover intention. International Journal of Hospitality Management, 55, 25-32. https://doi.org/10.1016/j.ijhm.2016.02.007

Ingram, V. J., de Grip, K., de Wildt, M. D. R., Ton, G., Douma, M., Boone, J. A., \& van Hoeven, J. T. (2013). Corporate social responsibility: The role of public policy. A systematic literature review of the effects of government supported interventions on the corporate social responsibility (CSR) behaviour of enterprises in developing countries. IOB study (No. 377). Department (IOB), Ministry of Foreign Affairs of the Netherlands.

Ioannou, I., \& Serafeim, G. (2015). The impact of corporate social responsibility on investment recommendations: Analysts' perceptions and shifting institutional logics. Strategic Management Journal, 36(7), 1053-1081. https://doi.org/10.1002/smj.2268

Jogdand, M. B., \& Sawant, M. A (2013). Study of the importance performance analysis of CSR activities of hotel industry in Aurangabad. In M. Sawant \& Ragde (Eds.), Comtemporary tourism planning,inrospecting problems and prospects (pp. 206-214). India: India.

Lin, X. Q. (2017). How CSR affects customer trust, brand image and behavioral loyalty? An empirical study in hotel industry. Macau: university of Macau.

Liu, F., Wang, X., Tian, X., \& Tang, Y. (2017,). The effect of corporate social responsibility on hotel employees' work outcomes: The mediating role of organizational identification. In Service systems and service management, international conference (pp. 1-5). IEEE.

Luu, T. T. (2017). CSR and organizational citizenship behavior for the environment in hotel industry: The moderating roles of corporate entrepreneurship and employee attachment style. International Journal of Contemporary Hospitality Management, 29(11). https://doi.org/10.1108/IJCHM-02-2016-0080

McLennan, C., Becken, S., \& Watt, M. (2013). Learning through a cluster approach: Lessons from the implementation of six Australian tourism business sustainability programs. Journal of Cleaner Production, 111, 348-357. https://doi.org/10.1016/j.jclepro.2015.01.085

Milone, I., Ticcoli, J., \& Zappia, G. (2015). The Trentino hotel sector: An economic-equity analysis and future prospects. Retrieved from https://www.academia.edu

Prabhakar, R., \& Mishra, S. (2013). A study of corporate social responsibility in Indian organization: An introspection. In 21 st International business research conference. Ryerson University, Canada.

Priya, V. (2014). Corporate social responsibility issues and challenges in India. International Research Journal of Management Science \& Technology, 5(11).

Smith, M. (2015). The cost of volunteering: Consequences of voluntourism [Senior theses]. Retrieved from https://repository.upenn.edu

Smith, R. A., \& Ong, J. L. T. (2015). Corporate social responsibility and the operationalization challenge for global tourism organizations. Asia Pacific Journal of Tourism Research, 20(5), 487-499. https://doi.org/10.1080/10941665.2014.918555

Tingchi Liu, M., Anthony Wong, I., Shi, G., Chu, R., \& L. Brock, J. (2014). The impact of corporate social responsibility (CSR) performance and perceived brand quality on customer-based brand preference. Journal of Services Marketing, 28(3), 181-194. https://doi.org/10.1108/JSM-09-2012-0171

Vallespín, T. M. (2016). Budget transparency in local governments.

Vveinhardt, J., \& Andriukaitiene, R. (2017). Management culture as part of organizational culture in the context of corporate social responsibility implementation. Economics and Sociology, 10(3)-294-320. https://doi.org/10.14254/2071-789X.2017/10-3/21

Yadava, R. N., \& Sinha, B. (2016) .Scoring sustainability reports using GRI 2011 guidelines for assessing environmental, economic, and social dimensions of leading public and private Indian companies. Journal of Business Ethics, 138(3), 549-558. https://doi.org/10.1007/s10551-015-2597-1

Yap, G., \& Saha, S. (2013). Do political instability, terrorism, and corruption have deterring effects on tourism development even in the presence of UNESCO heritage? A cross-country panel estimate. Tourism

50 Consortia Academia Publishing (A partner of Network of Professional Researchers and Educators) 
Evaluation on CSR issues in the view of hotel business in CALABARZON region, Philippines Analysis, 18(5), 587-599. https://doi.org/10.3727/108354213X13782245307911

Zientara, P., Kujawski, L., \& Bohdanowicz-Godfrey, P. (2015). Corporate social responsibility and employee attitudes: evidence from a study of Polish hotel employees. Journal of Sustainable Tourism, 23(6), 859-880. https://doi.org/10.1080/09669582.2015.1019511 
Borbon, N. M. D.

52 Consortia Academia Publishing (A partner of Network of Professional Researchers and Educators) 